\title{
Interelasi kecerdasan sosial dengan interaksi sosial mahasiswa luar Jawa Fakultas Ilmu Sosial Universitas Negeri Malang
}

\author{
Mochamad Ilham Akbar, Tasya Kartika Chandra, Riska Ayu Setyowati, Faizah Isnaeni, \\ Safira Lailatuz Zahro, Ananda Dwitha Yuniar*
}

Universitas Negeri Malang, Jl. Semarang No. 5 Malang, Jawa Timur, Indonesia

*Penulis korespondensi, Surel: ananda.dwitha.fis@um.ac.id

Paper received: 01-05-2021; revised: 15-05-2021; accepted: 30-05-2021

\begin{abstract}
Social intelligence is an individual's ability to take action and mindset in living life as a social being. Social intelligence is used by individuals to interact and understand other individuals, phenomena or the environment around them. This social intelligence consists of basic empathy, listening, empathic accuracy, and social understanding or cognition. Meanwhile, this social facility consists of synchrony, self-presentation, influence, and care. At this time in the world of academia, it focuses more on critical thinking which tends to lead to intellectual intelligence. Social intelligence is very important for students in the world of academia and for their adjustment to the social environment which is useful as a support for social life. It is important for a student to have social intelligence so that his life is balanced between his intellectual and social abilities. Because with social intelligence, students will find it easier to build good relationships with the community. the importance of social intelligence for students needs to be studied in academia at this time. To study this, the researcher examined the interrelation of social intelligence with the social interaction of students outside Java at the Faculty of Social Sciences, State University of Malang. The research method used was a qualitative method with a descriptive approach. The data collection techniques used were observation and interviews.
\end{abstract}

Keywords: social interaction; social intelligence; social adaptation

\begin{abstract}
Abstrak
Kecerdasan sosial merupakan kemampuan individu dalam melakukan tindakan dan pola pikir dalam menjalani kehidupan sebagai makhluk sosial. Kecerdasan sosial digunakan oleh individu untuk berinteraksi dan memahami individu lain, fenomena atau lingkungan disekitarnya. Kecerdasan sosial ini terdiri dari empati dasar, mendengarkan, ketepatan empatik, dan pengertian atau kognisi sosial. Sedangkan fasilitas sosial ini terdiri dari sinkroni, presentasi diri, pengaruh, dan kepedulian. Pada saat ini dalam dunia akademisi lebih menitik beratkan pada pemikiran kritis yang cenderung mengarah pada kecerdasan intelektual. Kecerdasan sosial sangat penting bagi mahasiswa dalam dunia akademisi dan untuk penyesuaian diri terhadap lingkungan sosial yang berguna sebagai penunjang kehidupan bermasyarakat. Kecerdasan sosial penting dimiliki oleh seorang mahasiswa agar kehidupannya seimbang antara kemampuan intelektual dan sosialnya. Karena dengan adanya kecerdasan sosial maka mahasiswa akan lebih mudah membangun hubungan yang baik dengan masyarakat. pentingnya kecerdasan sosial bagi mahasiswa ini perlu untuk dikaji dalam dunia akademisi pada saat ini. Untuk mengkaji hal ini, peneliti mengkaji interelasi kecerdasan sosial terhadap interaksi sosial mahasiswa luar jawa di Fakultas Ilmu Sosial Universitas Negeri Malang dengan metode penelitian yang peneliti gunakan adalah metode kualitatif dengan pendekatan deskriptif dengan teknik observasi dan wawancara sebagai teknik pengumpulan data.
\end{abstract}

Kata kunci: interaksi sosial; kecerdasan sosial; adaptasi sosial

\section{Pendahuluan}

Kecerdasan sosial merupakan kemampuan individu dalam mencapai kedewasaan pada pola berpikir maupun bertindak guna menjalani kehidupan sebagai makhluk sosial serta 
berinteraksi baik dengan lingkungan sekitarnya.Menurut Goleman (2007) dalam (Alfiasri et al., 2011), kecerdasan sosial merupakan sebuah kemampuan untuk memahami seseorang dan reaksi seseorang menyikapi fenomena sosial yang berbeda.Ada dua unsur kecerdasan sosial,yaitu kesadaran dan fasilitas sosial.Kecerdasan sosial ini terdiri dari empati dasar,mendengarkan,ketepatan empatik dan pengertian atau kognisi sosial. Sedangkan fasilitas sosial ini terdiri dari sinkroni, presentasi diri, pengaruh, dan kepedulian.

Saat ini, pada umumnya dalam sebuah dunia akademisi lebih menitik beratkan pada pemikiran kritis yang cenderung mengarah pada kecerdasan intelektual. Dirancang dengan sungguh-sungguh pada konsentrasi yang terdapat pada setiap spesifikasi guna kemampuan dalam menganalisis maupun sintetis dirasakan belum mencukupi untuk memberikan hal yang terfokus pada kecerdasan sosial. Kecerdasan sosial sangat penting untuk mahasiswa agar bisa melakukan penyesuaian diri terhadap lingkungan sosial, sebagai penunjang kehidupan bermasyarakat.

Kecerdasan sosial penting dimiliki oleh seorang mahasiswa agar kehidupannya seimbang antara intelektual dan sosialnya. Karena dengan adanya kecerdasan sosial maka mahasiswa akan lebih mudah membangun hubungan yang baik dengan masyarakat. Misalnya saja saat KKN/PKL di masyarakat, dari segi keikutsertaan sudah mendekati target yang menjadi tujuan program yang telah direncanakan. Hal ini berbeda dengan bagaimana mahasiswa tersebut membangun hubungan dengan masyarakat agar programnya terlaksana dengan baik. Maka diperlukan kecerdasan sosial dalam hal ini.

Empati, sinkronisasi, dan ketepatan empatik merupakan unsur dari kecerdasan sosial. Menurut Baron \& Byrne (2003) merupakan keterampilan seseorang dalam merasakan apa yang orang lain rasakan. Berdasarkan pendapat tersebut, empati menggambarkan bagaimana kita memahami apa yang orang lain rasakan, baik secara perasaan maupun pikiran. Seorang mahasiswa penting memiliki rasa empati guna menunjang kehidupan sosialnya. Dengan memiliki rasa empati, maka seorang mahasiswa akan memiliki tenggang rasa yang baik terhadap sesama sehingga dia akan mudah membantu orang lain yang membutuhkan bantuannya. Menurut hasil wawancara yang telah peneliti lakukan, beberapa narasumber mengatakan bahwa ketika ada teman yang mempunyai masalah mereka akan membantu sebisa mungkin, apabila mereka tidak bisa membantu maka setidaknya mereka memberikan dukungan. Dari sini, terlihat bahwa dengan memiliki rasa empati maka kita juga bisa membuat hubungan baik dengan teman.

Terkait dengan gambaran kecerdasan sosial pada mahasiswa, penelitian yang telah dilakukan oleh Annisa Andriani, Ratih Arruum Listiyandini (2017) menunjukkan bahwa kecerdasan sosial memiliki peran sebesar $16 \%$ terhadap kemampuan beradaptasi mahasiswa baru. Ditemukan fakta lain bahwa ternyata kecerdasan sosial juga berperan secara keseluruhan pada resiliensi mahasiswa baru. Sedangkan pada penelitian yang dilakukan oleh Nasehudin, kecerdasan sosial merupakan salah satu faktor penting yang harus dimiliki oleh seorang siswa guna menunjang kehidupan. Kecerdasan sosial tidak hanya sekedar bisa memahami apa yang dirasakan oleh individu lain, melainkan bisa memasuki diri individu tersebut, mampu mengerti pandangan individu lain.

Sementara itu dari hasil penelitian yang dilakukan oleh Afrom (2019) tentang hubungan kecerdasan sosial dengan kemampuan kerjasama kelompok belajar mahasiswa PGSD semester 1 Universita Palangkaraya menunjukkan bahwa semakin tinggi kecerdasan sosial mahasiswa 
maka akan semakin mudah dalam bekerja sama dengan kelompok belajar tersebut.Sedangkan penelitian yang dilakukan oleh Garvin (2017) tentang hubungan kecerdasan sosial dengan kesepian remaja menunjukkan semakin tinggi kecerdasan sosial remaja akan semakin rendah tingkat kesepian pada remaja,sebaliknya jika semakin rendah tingkat kecerdasan sosial remaja maka akan semakin tinggi kesepian pada remaja.

Fokus penelitian yang dilakukan adalah untuk mengetahui tingkat kecerdasan sosial pada mahasiswa sosiologi,Universitas Negeri Malang khususnya mahasiswa yang berasal dari luar Jawa, cara mereka menyesuaikan diri dan beradaptasi terhadap lingkungan disekitarnya terlebih dengan budaya yang baru mereka temui.

\section{Metode}

Metode penelitian yang peneliti gunakan adalah metode kualitatif dengan pendekatan deskriptif. Sampel yang digunakan dalam penelitian ini adalah purposive sampling dengan teknik pengumpulan data yang dilakukan adalah observasi dan wawancara. Wawancara yang dipilih adalah wawancara terbuka karena peneliti tidak mengetahui secara pasti jawaban yang diberikan informan. Wawancara dilakukan kepada mahasiswa yang berasal dari luar pulau jawa di Fakultas Ilmu Sosial Universitas Negeri Malang dengan jumlah 5 orang. Wawancara dilaksanakan di wilayah kampus Universitas Negeri Malang dan dilaksanakan pada tanggal 10 November 2019. Kemudian data dianalisis menggunakan teknik analisis Miles dan Huberman. Fokus dari penelitian ini adalah untuk meneliti dan menganalisis keterkaitan antara kecerdasan sosial dengan interaksi sosial dari mahasiswa yang berasal dari luar pulau jawa dalam beradaptasi di lingkungan sekitar yang berbeda dengan lingkungan tempat asal.

\section{Hasil dan Pembahasan}

Sebagai seorang mahasiswa tingkat awal, seorang individu pasti akan mengalami berbagai tuntutan baik dalam segi penyesuaian pembelajaran, penyesuaian terhadap lingkungan, dan dan tuntutan perkembangan (Sokol, 2009; Liebert, 2003; Gately, 2005 dalam Hernandez, 2007; Clark, 2005). Ketiga hal ini membutuhkan solusi yang mengarah pada peningkatan kualitas hubungan sosial individu guna memudahkan individu mencari identitas dirinya melalui interaksi sosial, dan juga untuk memudahkan individu dalam pemenuhan kebutuhan akademiknya. Dengan adanya kecerdasan sosial, mahasiswa akan lebih mudah menghadapi perubahan-perubahan yang terjadi.

Gardner (2009) mengemukakan bahwa kecerdasan sosial itu kemampuan yang dimiliki oleh seorang individu dalam berinteraksi atau berhubungan dengan orang lain. Seseorang apabila memiliki kecerdasan sosial yang baik maka dia akan mampu menjalin suatu komunikasi yang baik pula dengan lingkungan dan orang disekitarnya. Menurut Edward Thorndike, kecerdasan sosial adalah kemampuan untuk memahami dan mengelola pria dan wanita, anak laki-laki dan perempuan, untuk bertindak bijaksana dalam hubungan manusia (Syamsu, 2004). Alder (2001) juga berpendapat bahwa kecerdasan sosial merupakan suatu kemampuan memahami sekitar, memiliki hubungan yang baik dengan individu lain, dan kemampuan terampil dalam melakukan interaksi.

Jadi, dapat disimpulkan bahwa kecerdasan sosial adalah kemampuan seseorang atau individu dalam berinteraksi dengan individu lain atau orang lain. Jika seseorang itu memiliki kecerdasan sosial yang baik, maka ia akan dapat mengenali diri sendiri serta dapat menempatkan dirinya pada lingkungan di sekitarnya. 
Interaksi sosial merupakan sesuatu yang dibutuhkan oleh semua manusia, karena pada hakikatnya manusia merupakan makhluk sosial. Interaksi dapat berlangsung saat terjadi komunikasi baik secara langsung maupun secara tidak langsung dan kontak sosial primer maupun sekunder. Interaksi dapat terjadi saat adanya timbal balik antara individu dengan individu, individu dengan kelompok, maupun kelompok dengan kelompok.

Pada kenyataannya, interaksi sosial tidak hanya ada interaksi sosial yang mengarah pada penyatuan (asosiatif), namun ada interaksi sosial yang mengarah pada perpecahan (disosiatif). Interaksi sosial juga merupakan sesuatu yang dipengaruhi oleh kecerdasan sosial. Tingkat kecerdasan sosial yang dimiliki oleh seseorang tentu mempengaruhi kemampuan interaksi karena kecerdasan sosial mencakup tentang kemampuan seseorang dalam menyesuaikan diri dengan lingkungan, menghadapi suatu keadaan maupun saat berhadapan dengan orang lain, dll.

Berdasarkan hasil wawancara, kecerdasan sosial penting dimiliki oleh seorang mahasiswa karena dengan memiliki kecerdasan sosial maka mahasiswa tersebut juga memiliki kepekaan sosial, kedua hal ini berbanding lurus artinya semakin tinggi kecerdasan sosial seseorang maka akan semakin tinggi pula kepekaan sosial yang dia miliki Sebaliknya, semakin rendah kecerdasan sosial seseorang maka akan semakin rendah pula kepekaan sosial seseorang. Selain itu, semakin tinggi kesadaran sosial seseorang maka akan semakin tinggi pula kesadaran sosial seseorang, karena dalam kecerdasan sosial terdapat unsur kepedulian akan lingkungan. Selain itu, dengan adanya kecerdasan sosial seseorang akan mampu membedakan mana yang baik dan buruk sehingga kesadaran sosialnya pun ikut berkembang.

Goleman (2007) menyebutkan unsur kecerdasan sosial, yaitu kesadaran sosial dan fasilitas sosial. Dalam konteks ini, kesadaran sosial merupakan sesuatu yang kita rasakan dari orang lain, yaitu simpati. Simpati yang dimiliki orang yang memiliki kecerdasan sosial inilah yang mendukung terjalinnya suatu interaksi sosial. Sedangkan fasilitas sosial merupakan bentuk perwujudan dari kesadaran sosial. Fasilitas sosial merupakan sebuah tindakan yang dilakukan yang dilakukan dengan modal kesadaran sosial yang dimiliki misalnya empati.

Empati merupakan suatu kondisi dimana seseorang dapat menempatkan diri pada posisi dan kondisi orang lain dan berbagi kesedihan bersama. Empati pertama kali diperkenalkan oleh seorang psikologi asal Amerika bernama E. B. Tichener, dirinya menyatakan bahwa empati merupakan sifat yang berasal dari peniruan peniruan secara fisik atas beban orang lain yang kemudian timbul perasaan yang sama dalam dirinya (Goleman, 1996). Empati merupakan kemampuan untuk melihat situasi yang terjadi dari perspektif orang lain, di dalam empati melibatkan aspek sudut pandang, emosi, dan kesulitan yang sedang dialami oleh seseorang dengan menempatkan diri pada posisi mereka dan juga turut merasakan apa yang sedang mereka alami.

Perilaku empati dapat mengurangi intoleransi, konflik dan diskriminasi, serta empati dapat meningkatkan pemahaman akan rasa hormat dan toleransi terkait dengan perbedaan. Di dalam kecerdasan sosial, rasa empati membuat sebuah hubungan yang dijalin oleh seseorang bisa menjadi lebih dekat karena dapat merasakan dan memahami perasaan, dan keadaan masing-masing. Dalam penelitian ini para mahasiswa merasakan sikap empati yang mereka ekspresikan ketika melihat teman atau sahabat yang sedang mengalami sebuah kesulitan, mereka mengekspresikan rasa empati mereka dengan membantu teman yang 
sedang mengalami masalah dengan semampu dan sebisa mereka untuk mengurangi beban atau kesusahan yang sedang dialami teman mereka.

Dengan adanya kesadaran sosial maka seseorang akan lebih mudah berempati dengan orang lain. Dari wawancara yang didapat, mayoritas narasumber akan membantu orang lain yang sedang kesusahan, entah membantu secara tenaga ataupun sekedar memberikan katakata semangat.

Beberapa informan memaparkan bahwa mereka terkadang merasa jengkel dengan teman yang jika diajak berdiskusi tidak merespon dengan sesuai yang diharapkan. Namun karena mereka mengetahui hakikat kecerdasan sosial, mereka mampu menggunakan kecerdasan sosial mereka untuk beradaptasi dengan mahasiswa lain. Dengan memiliki kecerdasan sosial seseorang akan lebih bisa mengatur atau mengontrol dirinya sendiri. Seperti hasil wawancara, meskipun terkadang mahasiswa tersebut merasa jengkel ketika berkomunikasi dengan orang lain yang kurang tanggap namun mereka tetap bisa menghargai orang tersebut tanpa menghinanya. Disinilah pentingnya kecerdasan sosial yang dimiliki mahasiswa.

Sosialisasi merupakan aspek yang mempengaruhi individu sebagai gejala sosial, Sosialisasi menurut Buehler (2007) merupakan sebuah proses belajar dan menyesuaikan diri bagi individu tentang bagaimana cara hidup dan berpikir agar berperan dan dapat berfungsi dalam kelompoknya. Sosialisasi terbagi menjadi dua bagian, yakni sosialisasi primer dan sekunder. Sosialisasi primer terjadi di dalam keluarga yang merupakan lingkungan utama dalam sosialisasi. Sosialisasi sekunder terjadi di luar lingkungan keluarga, dapat berupa sekolah, dan teman sebaya. Proses sosialisasi terjadi melalui interaksi sosial dan membentuk perilaku yang terbentuk dari pengalaman dan dipengaruhi oleh watak pribadinya, yaitu dengan cara memberi reaksi terhadap suatu pengalaman.

Dalam penelitian ini mahasiswa yang berasal dari luar jawa melakukan sosialisasi dengan menyesuaikan diri mereka dalam keadaan dan lingkungan dimana mereka berada, mereka melakukan adaptasi dengan lingkungan yang mereka hadapi baik didalam lingkungan universitas dan diluar universitas, terutama lingkungan Universitas Negeri Malang yang bukan lingkungan asli mereka. Jika mahasiswa itu dihadapkan dengan lingkungan yang tidak sesuai dengan diri pribadi para mahasiswa, mereka banyak yang memberi tanggapan akan mencoba untuk beradaptasi dan mengenal lingkungan mereka tersebut agar mereka bisa merasa nyaman dan dianggap mampu untuk bersosialisasi dengan sekitar.

Untuk mengamalkan kecerdasan sosial yang dimiliki, para mahasiswa banyak yang mengikuti kegiatan di dalam kampus maupun diluar, seperti mengikuti organisasi yang ada, mengikuti seminar, juga ikut berkumpul dan bersosialisasi dengan mahasiswa lain di luar kampus seperti kegiatan diskusi ataupun sekedar berkumpul. Sedangkan, dari segi budaya sendiri, mahasiswa yang berasal dari luar pulau jawa mengalami culture shock karena baik dari segi sosial maupun geografis berbeda dengan tempat asal mereka. Untuk itu, mahasiswa yang berasal dari luar pulau jawa pasti akan berusaha lebih ketika sosialisasi, seperti dengan mencari teman yang berasal dari tempat asal yang sama atau yang berasal dari berbagai pulau. Dengan demikian, mahasiswa yang berasal dari luar pulau jawa harus menyesuaikan baik dalam bentuk komunikasi maupun sosial budaya. Hal ini dikarenakan mayoritas mahasiswa Universitas Negeri Malang berasal dari pulau jawa. 
Kecerdasan sosial yang dimiliki seorang mahasiswa bisa membantunya dalam proses penyesuaian diri, terutama mahasiswa yang berasal dari luar pulau jawa. Langkah awal penyesuaian diri bisa dilakukan melalui bahasa. Bahasa merupakan media dalam berkomunikasi, sehingga bahasa penting guna menunjang keberhasilan dalam komunikasi.

Dari penuturan mahasiswa yang berasal dari luar pulau jawa, sebagian dari mereka mengalami kesulitan karena bahasa. Hal ini disebabkan karena keseharian mereka ketika di daerah asalnya menggunakan bahasa maupun logat daerah. Sedangkan di Malang mayoritas menggunakan bahasa Jawa. Mereka mengalami kesulitan karena bahasa yang digunakan berbeda, sekalipun bahasa yang digunakan sama-sama bahasa indonesia namun jika logatnya berbeda maka akan lebih sulit memahami.

\section{Simpulan}

Interaksi sosial sangat erat hubungannya dengan kecerdasan sosial. Individu yang memiliki kecerdasan sosial yang tinggi akan mampu berinteraksi dengan baik. Hal ini dikarenakan individu yang memiliki kecerdasan sosial akan mempengaruhi kemampuan berbahasa, emosi, maupun intelektual. Dalam kehidupan mahasiswa, mereka membutuhkan kecerdasan sosial untuk berinteraksi baik di dalam maupun di luar lingkungan universitas. Tidak hanya mahasiswa yang berasal dari daerah tempat universitas tersebut namun juga yang berasal dari luar daerah contohnya luar pulau jawa. Bagi mahasiswa Universitas Negeri Malang yang berasal dari luar pulau jawa, mereka menyatakan bahwa kecerdasan sosial sangat mereka butuhkan dalam berinteraksi dalam lingkungan baru. Mereka beranggapan bahwa dengan memiliki kecerdasan sosial mereka memiliki kepekaan sosial yang salah satunya dapat mereka ekspresikan dalam wujud empati. Mereka juga melakukan sosialisasi untuk beradaptasi dan menyesuaikan diri agar mereka menjadi bagian dari lingkungan yang mereka hadapi, mereka mengikuti kegiatan berupa organisasi atau mengikuti seminar untuk bersosialisasi. namun, dalam aspek budaya mereka masih mengalami culture shock karena dalam segi sosial dan geografis sangat berbeda dengan tempat asal mereka, para mahasiswa tersebut mengalami kendala dalam hal bahasa karena ketika di daerah asalnya menggunakan bahasa maupun logat daerah, kemudian saat berada di Malang mereka merasa kesulitan karena bahasa daerah yang berbeda.

\section{Daftar Rujukan}

Afrom, I. (2019). Hubungan Kecerdasan Sosial dengan Kemempuan Kerja Sama dalam Kelompok Belajar Mahasiswa PGSD Semester I Universitas Palangka Raya. Pedagogik: Jurnal Pendidikan, 14(1), 77-81.

Alfiasari, A., Latifah, M., \& Wulandari, A. (2011). Pengasuhan otoriter berpotensi menurunkan kecerdasan sosial, self esteem, dan prestasi akademik remaja. Jurnal Ilmu Keluarga \& Konsumen, 4(1), 46-56.

Andriani, A., \& Listiyandini, R. A. (2017). Peran kecerdasan sosial terhadap resiliensi pada mahasiswa tingkat awal. Psympathic: Jurnal Ilmiah Psikologi, 4(1), 67-90.

Fadli, M., \& Djamhuri, A. (2013). Pengaruh Kecerdasan Emosional, Kecerdasan Spiritual, dan Kecerdasan Sosial Terhadap Sikap Etis Mahasiswa Akuntansi (Studi Pada Universitas Negeri di Kota Malang). Jurnal Ilmiah Mahasiswa FEB, 2(2).

Garvin, G. (2017). Hubungan Kecerdasan Sosial dengan Kesepian pada Remaja. Jurnal Muara Ilmu Sosial, Humaniora, dan Seni, 1(2), 93-99.

Goleman, D. (2007). Emotional intelligence: Mengapa EI lebih penting daripada IQ. Jakarta: Gramedia Pustaka.

Nasehudin, N. (2016). Mengembangkan kecerdasan sosial dalam proses pendidikan. Edueksos: Jurnal Pendidikan Sosial \& Ekonomi, 4(2). 
Jurnal Integrasi dan Harmoni Inovatif Ilmu-Ilmu Sosial, 1(5), 2021, 598-604

Pariosi, T. K. (2013). Kecerdasan Sosial Guru. Jurnal Online Psikologi, 1(2).

Riadi, M. (2018). Pengertian, Aspek dan Cara Meningkatkan Kecerdasan Sosial, https://www.kajianpustaka.com/2018/01/pengertian-aspek-dan-cara-meningkatkan-kecerdasan-sosial.html

Seputarpengetahuan.co.id. (2018). Pengertian Kecerdasan Sosial, Ciri, Aspek \& Faktor Pengaruhnya. https://www.seputarpengetahuan.co.id/2018/05/pengertian-kecerdasan-sosial-ciri-ciri-aspekfaktor-yang-mempengaruhi.html

Sokol, J.T. (2009). Identity Development throughout the Lifetime: An Examination of Eriksonian Theory. Graduate Journal of Counseling Psychology, 1(2), Article: 14. http://epublications.marquette.edu/gjc $\mathrm{p} / \mathrm{vol} 1 /$ iss2/14.

Yusup, F. (2019). Mengembangkan Kecerdasan Sosial. https://uin-antasari.ac.id/mengembangkankecerdasan-sosial-febrianawati-yusup/ 